\title{
Groundwater Quality of Disi-Aquifer in Southern Jordan
}

\author{
Mehaysen Ahmed Mahasneh* \\ Chemical Engineering Department, Al-Huson University Collage, Al-Balq'a Applied University \\ *Corresponding author: m.mahasneh@bau.edu.jo, mahsneh2008@hotmail.com
}

\begin{abstract}
The aquifer is composed of rock units overlaying the basement complex of the Precambrian ERA are subdivided into two groups: the upper group is called Khreim group, and the lower group is the Rum group. These formations are Saleb, Burj, Umm Ishrin, Disi, and Umm Sahm formations. The rock formations constituting the Rum group compose the Rum aquifer system, which dominates the fresh water aquifer system in southern Jordan which the aquifer system in southern Jordan which the rock formations constituting the Khreim group represent the confining layer where Sahl Suwaan formation occur. The Disi aquifer, which is the main source of water for Mudawara Region, is one of the most permeable and productive Sandstone aquifers in the Jordan. The groundwater flows from the Saudi Arabia in the South towards North East Jordan in central Jordan. The Rum aquifer system represents an unconfined aquifer system in the area in which no deposition of Khreim group where Khreim group overlies the Rum sandstone deposits. The most important feature of the Rum aquifer is its homogeneity in the grain size ranges between $0.25 \mathrm{~mm}$ to $0.51 \mathrm{~mm}$ sand, the uniformity coefficient ranges between 1.36 to 2.19 at different formations depth between $330 \mathrm{~m}$ to $520 \mathrm{~m}$, medium to fine and medium to coarse uniformly graded sand of different formations. The large transmissivity of the Disi aquifer is indicated between 541 to $656 \mathrm{~m}^{2} /$ day of yielding wells and the storage coefficient in the range 0.0199 to 0.0260 , the specific capacity in range 5.9 to $7.11 \mathrm{l} / \mathrm{s} / \mathrm{m}$. The obtained results were found to be corresponded to the unconfined nature of in the encountered aquifers in A1, A2, A3, A4, A5, A6, A7, A8, and B1, B2, B3, B4 wells, and this is clearly indicated in the storage coefficient (specific yield) of this aquifer in these wells. The results of water sample analyses show water quality is excellent and acceptable for drinking purposes, according to the Jordanian water standard 2008, and EU drinking water standard 1998.
\end{abstract}

Keywords: aquifer, rum, Southern Jordan, drinking, turbidity, Sahl Suwaan, water quality, water level, sand stone

Cite This Article: Mehaysen Ahmed Mahasneh, “Groundwater Quality of Disi-Aquifer in Southern Jordan.” American Journal of Water Resources, vol. 5, no. 5 (2017): 152-161. doi: 10.12691/ajwr-5-5-3.

\section{Introduction}

Based on the outcrop geology of the Mudawrra Southern groundwater basin in Jordan, the different rock units overlying the basement complex of the Precambrian ERA are subdivided into two groups: the upper group is called Khreim group, and the lower group is the Rum group [1].

These formations are Saleb, Burj, Umm Ishrin, Disi, and Umm Sahm formations. The Khreim Group consists from bottom to top of Shal Suwaan, Um Tarifa, Trabeel, Batra and Alna Formations [4, 5].

The rock formations constituting the Rum group compose the Rum aquifer system, which is dominant fresh water aquifer system in southern Jordan which the rock formations constituting the Khreim group represent the confining layer where Sahl Suwaan formations occur.

The rest of the formation from a leaky aguitard containing relatively highly saline water. The Rum aquifer system represents an unconfined aquifer system in the area in which no deposition of Khreim group occurring and it represent a confined aquifer system in the area where Khreim group overlies the Rum sandstone deposits [2].

\section{Hydrogeology of Disi-Mudawarra}

The Rum Aquifer encompasses the stratigraphic units of the Rum Group [3] and is overlies by the leaky layers of the Khreim Group [6].

The lower part of Hiswa Formation (Khreim Group) consists of mudstone and confines the Rum Aquifer in the northeastern part of the Disi area. To the West and Southwest, where there are outcrops of Umm Sahm Formation, the aquifer is unconfined, from its western boundary, the aquifer thickens eastwards in excess of 1000 meters.

The general groundwater flow direction is to northeast as shown in Figure 1. The piezometric surface in the project area is between 720 and $740 \mathrm{~m}$ amsl, which corresponds to water level depths of between 100 and 200m below ground level. The hydraulic conductivity ranges from 1 to $4 \mathrm{~m} /$ day.

The groundwater velocity equation can be derived from a combination of Darcy's law and the velocity equation of: 


$$
\begin{aligned}
& \mathrm{Q}=\mathrm{KA}\left(\frac{\mathrm{dh}}{\mathrm{dl}}\right) \text { (Darcy's law) } \\
& \mathrm{Q}=\mathrm{Av} \text { (Velocity equation) }
\end{aligned}
$$

Where $\mathrm{Q}$ is the rate of flow or volume per unit of time, $\mathrm{K}$ is the hydraulic conductivity [7], A is the cross-sectional area, at a right angle to the flow direction, through which the flow Q occurs, $\mathrm{dh} / \mathrm{dl}$ is the hydraulic gradient, and $\mathrm{v}$ is the Darcian velocity, which is the average velocity of the entire cross-sectional area. Combining these equations, we obtain:

$$
\mathrm{Av}=\mathrm{KA}(\mathrm{dh} / \mathrm{dl}) \text {. }
$$

Canceling the area terms, we find that

$$
v=K\left(\frac{d h}{d l}\right) .
$$

Ground-water velocity also depends on the porosity of rock (n) because, as we know, water moves only through the porous media by a rock. Adding the porosity term, we obtain:

$$
v=\frac{K d l}{n d l} .
$$

Hydraulic conductivity ranges from 1 to $4 \mathrm{~m} / \mathrm{day}$. Groundwater quality in generals good with Total Dissolved Solids (TDS) around 200 -300 mg/l, electrical conductivity (EC) values around $350-400 \mu \mathrm{S} / \mathrm{cm}$, and $\mathrm{pH}$ values around 7 .

According to the rock formations in southern Jordan. The Precambrian basement complex represents the base of the Rum aquifer system. The Rum aquifer system presents an unconfined aquifer in the areas between where it directly overlies the basement and it directly underlies the Khreim Group Figure 1. Generally, the Disi -Mudawarra area is bisected by many faults with different directions.

The two major directions are northwest -Southeast and northeast -Southwest and the two minor fault systems are in the direction of North -South and East -West. The inter - relationship between the Rum aquifer and Khreim aquitard is represented in a simplified Hydrogeological cross section in the Figure 1.

The Rum group extends to the South where it is exposed in Saudi Arabia and similar forms unconfined and confined aquifer systems.

The Rum aquifer system in southern Jordan is extended into Saudi Arabia, where it is known as Sag aquifer system and both actually from one aquifer system [2].

Generally, the groundwater flows from the Saudi Arabia in the South towards North East Jordan in central Jordan it deviates to North West and lastly towards West, where it discharges its water in the Dead Sea and in the deep Wadis draining the eastern highlands towards the Rift Valley [12].

The most important feature of the Rum aquifer is its homogeneity in the grain size ranges between $0.25 \mathrm{~mm}$ to $0.51 \mathrm{~mm}$ sand, the uniformity coefficient ranges between 1.36 to 2.19 at different formations depth between 330m to $520 \mathrm{~m}$, medium to fine and medium to coarse uniformly graded sand of different formations constituting the aquifer except local lateral finer grains especially in Umm Sham formation.

The total thickness of the Rum aquifer is about 12oom, and this thickness is usually decreased towards its marginal exposure in the west.

A confining layer, the Haswa Shale of Khreim group, overlies the Rum aquifer. The thickness of this confining layer is almost uniform of $50 \mathrm{~m}$. The rest of the formation of the Khreim group represents a leaky layer of a thickness ranging between $400 \mathrm{~m}$ and $1200 \mathrm{~m}$ and normally contain saline water.

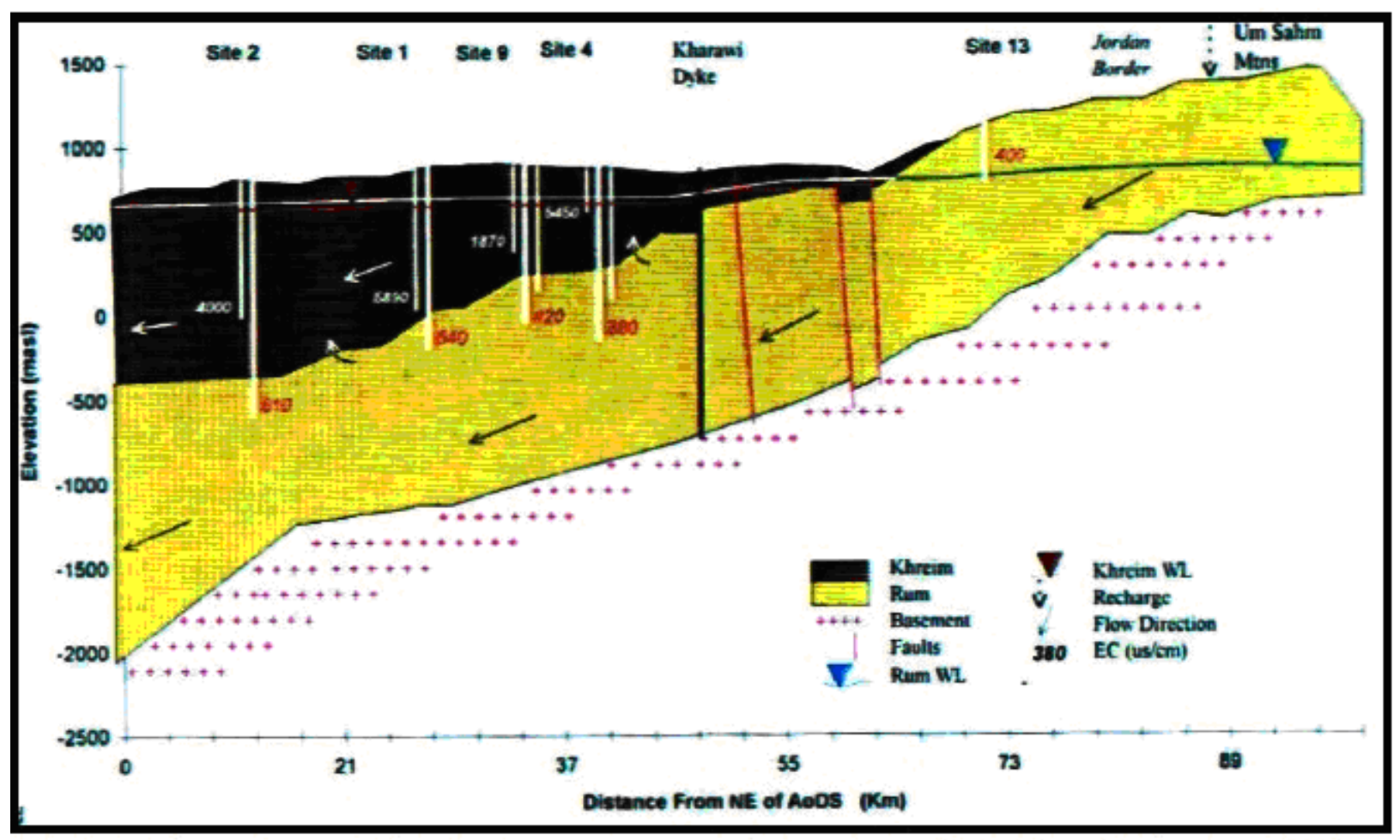

Figure 1. Hydrogeological cross-section showing relationship between Rum Aquifer and Khreim Aquitard 


\section{Aquifer System}

In the area located between Disi and Mudawarra there are many wells drilled during the last five decades. Most of these wells were drilled during the last two decades.

The quantity water from these wells are used for domestic, industrial purposes in Aqaba, domest local communities distributed all over the area and most of the quantities amount is used for agricultural purposes utilized by many agricultural companies.

The amounts from the Disi -Mudawarra area were taken from both the unconfined aquifer in Disi -Sahl Suwaan area, and the confined aquifer in the Mudawarra area.

\subsection{Dubaydib Well Field}

Due to the nature of the water quality that occurs in the confining layer of the Rum aquifer, the study conducted by Brown and Root suggested locating the well field to produce the necessary amount of water in Dubaydib.

As mentioned before, the water quality in this area is considered excellent water and there are no deposits of the Khreim group present in the area where the water occurs in unconfined conditions. For more emphasis on the nature of the aquifer and water type present in Dubadydib well filed area, three wells were located and drilled under the supervision of Two wells [3] of these three wells were drilled and tested and the third one is drilled as an observation well in Dubaydib area. A summary of these wells is presented in Table 1. The Disi Mudawarra to Amman Water Conveyance system Project, were drilled 55 production wells, and 9 piezometeric wells (observations) in the Dubaydib wells filed.

The hydraulic characteristics of the aquifer encountered in the A1, A2, A3, A4, A5, A6, A7, A8 and B1, B2, B3, B4, wells were calculated from the well testing production and observation wells supervised by all companies in the project.

\subsection{Geophyiscal Logging}

A composite log of the geophysical logging data. Detailed geophysical logs are presented the characteristic ranges of values for the key indicators are presented for the lithologies existing in the Project area:
Table 1. Characteristic geophysical properties of rocks

\begin{tabular}{|c|c|c|c|}
\hline lithologies & $\begin{array}{c}\text { Natural } \\
\text { Gamma [cps] }\end{array}$ & $\begin{array}{c}\text { App. Resistivity } \\
\text { [ohmm] }\end{array}$ & $\begin{array}{c}\text { Density } \\
\text { [g/cm } \mathbf{}^{3} \text { ] }\end{array}$ \\
\hline Sandstone & $5-10$ & $50-500$ & $2.65-2.80$ \\
\hline Siltstone & $50-100$ & up to 100 & $2.45-2.60$ \\
\hline Mudstone & $50-100$ & up to 50 & $2.35-2.45$ \\
\hline Shale & $100-200$ & up to 15 & $2.00-2.35$ \\
\hline
\end{tabular}

Table 1. Show how the natural gamma is increasing from 15 - 20 cps to 20 - 30 cps between $40 \mathrm{~m}$ and $74 \mathrm{~m}$, and the effect on the mud level can be recognized. In $158 \mathrm{~m}$ depth there is a significant drop down to values around 5-10 cps. Figure 2. Show the Geophysical logging Between $158 \mathrm{~m}$ and a TD.

The gamma readings are more or less constant around 5 - 10 cps, except some values in $178 \mathrm{~m}, 322 \mathrm{~m}, 347 \mathrm{~m}$, 370 - 383m, 420m and 511m depth. These peaks are characterizing zones of higher clay and/or silt content within the Formation.

From the lithological description, in combination with observation of natural gamma radiation, the two stratigraphic groups are clearly identified.

Khreim group, is more Silty Sandstone and Mudstone and including Dubaydib and Hiswa Formations, from $0 \mathrm{~m}$ to $158 \mathrm{~m}$ depth (around $15-50 \mathrm{cps}$ ).

The Rum group, including Umm Sahm Formation at least, with the lowest values of natural gamma radiation (5-10cps, corresponding to clean sandstone) from $158 \mathrm{~m}$ to the total depth of the borehole $(525.00 \mathrm{~m})$.

The Dubaydib sandstone Formation is encountered down to $50 \mathrm{~m}$, where the base of a deposition cycle is marked by both a very characteristic gamma anomaly (around 15-25 cps) and brownish sandstone with ferruginous cement that can be traced over most of the area.

The resistivity logs Records start at 40m showing only low readings in the values for shallow and deep apparent resistivity until 158m depth with low apparent resistivity of around 13ohmm and long apparent resistivity of around $30 \mathrm{ohmm}$ where the low permeability of the whole drilled section is observed.

After 158m, increasing in the produce section the apparent resistivity pattern is quite uniform, a significant increase in apparent resistivity and also a bigger spread between the short and long spaced measurement is recognized.

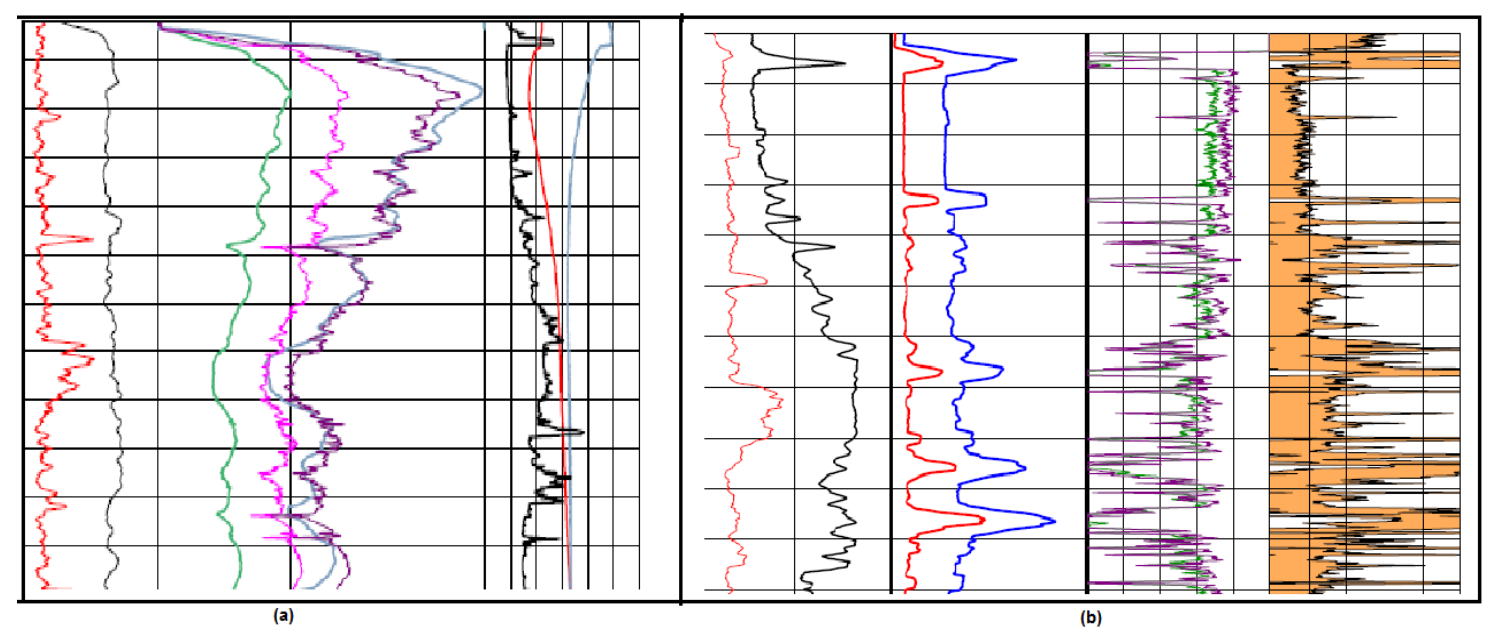

Figure 2. (a). geophysical logging Data (b). Final composite log 


\subsection{Pumping Tests}

The bottom of the Hiswa Formation was encountered at a depth of $158 \mathrm{~m}$. As the ISWL was recorded at $101.40 \mathrm{~m}$ bRP, wells are located in the confined and unconfined of the aquifer. The discharge rate was measured both by a weir tank and by an electromagnetic flow meter.

\subsubsection{Step Drawdown Pumping Test (SDPT)}

The SDPT took 15 hours. It comprised five consecutive steps of 3 hours each, with discharge rates of 42.19, 56.16, 69.72, 91.49 and $108.57 \mathrm{l} / \mathrm{s}$. The pumping phase was followed by 24-hour recovery period Figure 3.

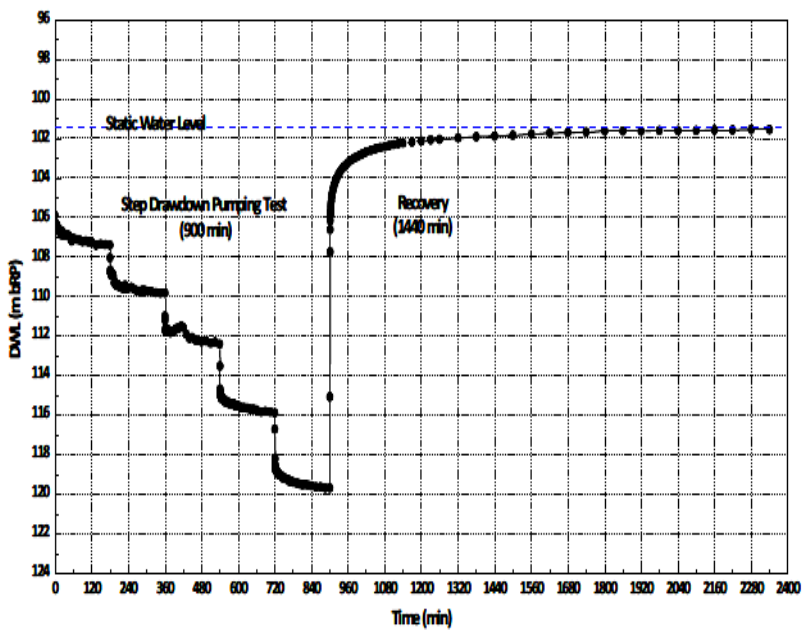

Figure 3. Water level measurements during the SDPT and recovery

\subsubsection{Steady Rate Pumping Test (SRPT)}

The SRPT took 24 hours at the constant discharge rate of $79.20 \mathrm{l} / \mathrm{s}$. The drawdown at the end of the pumping phase was $13.21 \mathrm{~m}$. This was followed by a 24-hour recovery period Figure 4 .

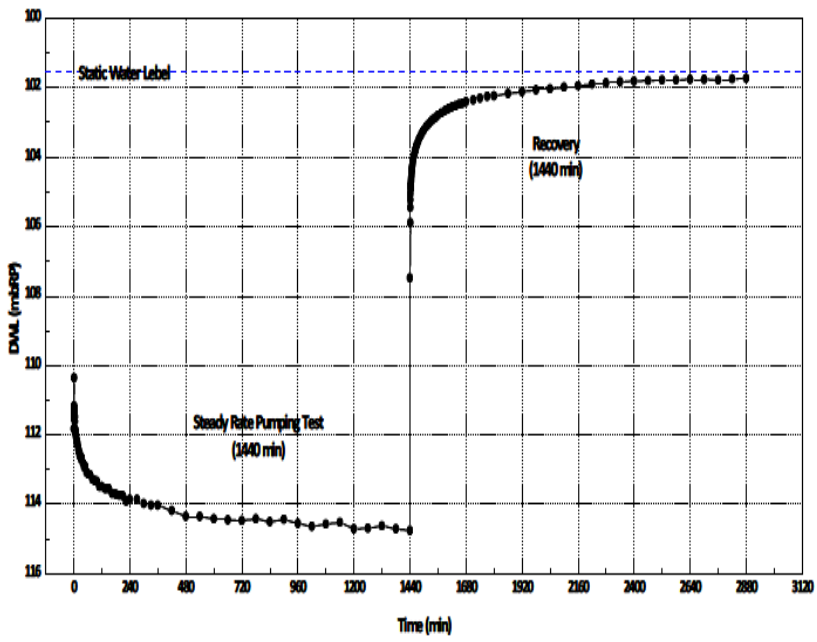

Figure 4. Water level measurements during the SRPT and recovery

\subsubsection{Flow Meter Logging}

The flow meter logging in the production section was performed when full recovery after the SDPT was achieved. The logging was done in two modes, as follows:
- The flow meter run inside the Pump house Casing Section without any pumping from 165 to $220 \mathrm{~m}$.

- Flow meter logging in the Production Section while pumping (dynamic mode) from 290 to 510m. All data are graphically presented in the Figure 5.

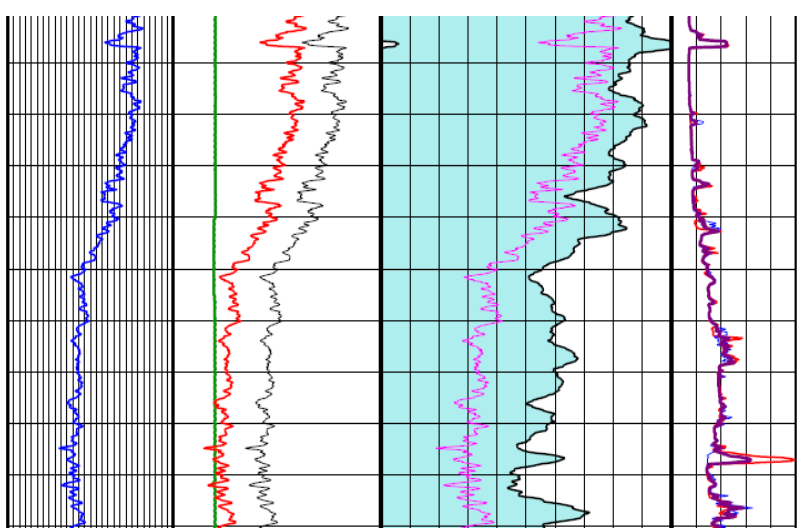

Figure 5. Flow meter logging drawdown/ open hole completion

Flow meter logging data interpretation - Section to be completed later on Flow meter log measurements were carried out during SRPT with a discharge of $79.2 \mathrm{l} / \mathrm{s}$. The integration of the flow measurements over the depth as the tool passes down the Production Section is shown in Figure 5.

The distribution of the flow over the screened sections is presented in Table 2. Interpretation of the flow meter data according to the flow meter logging is, $45 \%$ (36 l/s) of the total discharge flows into the well from the depth interval 397 - 453m bgl, $30 \%$ (24 l/s) from 306 - 344m bgl and $25 \%$ (20 l/s) from 499 - 520m bgl.

Table 2. Results of flow meter logging with a pumping rate of $79.2 \mathrm{l} / \mathrm{s}$

\begin{tabular}{|c|c|c|c|c|c|}
\hline $\begin{array}{c}\text { Inflow } \\
\text { interval }\end{array}$ & \multicolumn{2}{|c|}{$\begin{array}{c}\text { Depth } \\
\text { Interval }\end{array}$} & Length & $\begin{array}{c}\text { Discharge per } \\
\text { productive } \\
\text { interval }\end{array}$ & $\begin{array}{c}\text { Part of the } \\
\text { total } \\
\text { discharge }\end{array}$ \\
\hline No. & \multicolumn{2}{|c|}{$[\mathrm{m}$ bgl] } & {$[\mathrm{m}]$} & {$[\mathrm{l} / \mathrm{s}]$} & {$[\%]$} \\
\hline 1 & 306 & 308 & 2 & 9 & 11.3 \\
\hline 2 & 322 & 324 & 2 & 6 & 7.5 \\
\hline 3 & 342 & 344 & 2 & 9 & 11.3 \\
\hline 4 & 397 & 399 & 2 & 12 & 15 \\
\hline 5 & 402 & 432 & 30 & 18 & 22.5 \\
\hline 6 & 440 & 453 & 13 & 6 & 7.5 \\
\hline 7 & 499 & 520 & 21 & 20 & 25 \\
\hline
\end{tabular}

\subsubsection{Pumping Test Data Analyses}

The capacity of an aquifer to transmit water of the prevailing kinematic viscosity is referred to as its transmissivity.

The transmissivity ( $\mathrm{T}$ ) of an aquifer is equal to the hydraulic conductivity of the aquifer multiplied by the saturated thickness of the aquifer.

$$
T=K b
$$

Where: $\mathrm{T}$ is transmissivity, $\mathrm{K}$ is hydraulic conductivity, and $\mathrm{b}$ is aquifer thickness.

The combined the transmissivity with Darcy's law (see "Hydraulic conductivity"), the result is an equation that 
can be used to calculate the quantity of water (q) moving through a unit width (w) of an aquifer. Darcy's law is:

$$
Q=K A\left(\frac{d h}{d l}\right)(\text { Darcy'slaw }) \text {. }
$$

Expressing area (A) as bw, we obtain

$$
Q=K b w\left(\frac{d h}{d l}\right) \text {. }
$$

The expressing transmissivity $(\mathrm{T})$ as $\mathrm{Kb}$, we obtain:

$$
Q=T w\left(\frac{d h}{d l}\right)
$$

The derived transmissivity values are $\mathrm{T}=1.11 \mathrm{E}-02$ $\mathrm{m} 2 / \mathrm{S}=956 \mathrm{~m} 2 / \mathrm{d}$.

Thus, The obtained results were found to be corresponded to the unconfined nature of in the encountered aquifers in A1, A2, A3, A4, A5, A6, A7, A8 and B1, B2, B3, B4 wells, and this is clearly indicated in the storage coefficient.

The storage coefficient (S) is defined as the volume of water that an aquifer releases from or takes into storage per unit surface area of the aquifer per unit change in head. The storage coefficient is a dimensionless unit, as the following equation:

$$
S=\left(\frac{\text { volume of water }}{\text { (unit area) (unit head change) }}\right) \mathrm{m3} / \mathrm{m3} \text {. }
$$

The size of the storage coefficient depends on whether the aquifer is confined or unconfined. If the aquifer is confined, the water released from storage when the head declines comes from expansion of the water and from compression of the aquifer. Relative to a confined aquifer, the expansion of a given volume of water in response to a decline in pressure is very small.

The specific yield of this aquifer in these wells.A1, B1, (A1 0.0197 and 0.00987 for B1 with the specific yield of Disi unconfined.

This is attributed to the lithological nature of the Disi aquifer in the area of Dubaydib where it contains traces of coolant and micaceous silt interrelated the medium to coarse clean sandstone.

The A3 well is drilled in Dubaydid of the area where the aquifer is confined in nature. In the locality of A3 well, the confining layer of the Khreim Group is the Haswa formation, which is composed of shale, sandstone and clay stone of about $100 \mathrm{~m}$ in thickness. Due to this the calculated storage coefficient of the aquifer in A3 well is
(0.0200) represents a confined aquifer.

The B2 well, containing layers of the Khreim group is Haswa formation consists of mudstone and confines the Rum aquifer in the northeastern of the project area, where there are outcrops of um same formation. To evaluate and analyze the SDPT data, we used the Hantush- Bierschenk method $[8,9]$. As shown in Figure 6.

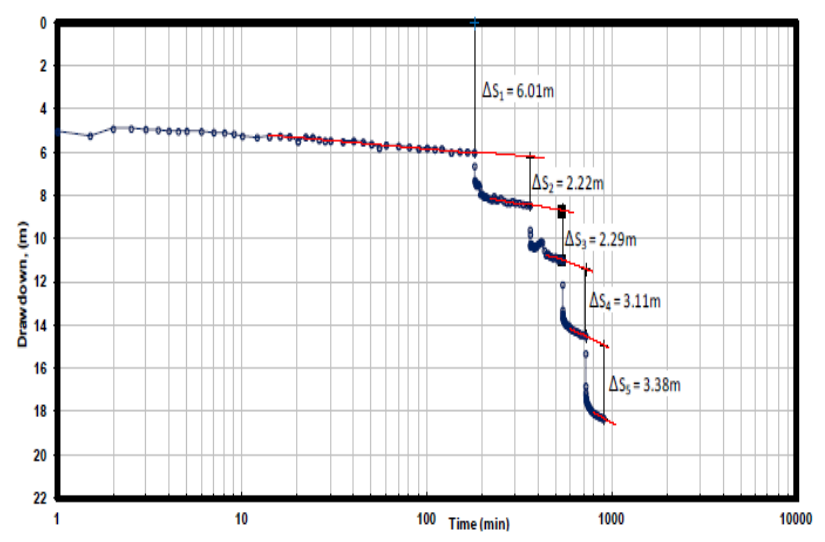

Figure 6. Step test analysis according to Hantush-Bierschenk method.

While the Jacob method [10,11] was used to evaluate the well efficiency as shown in Figure 7. Results are indicated in Table 3 .

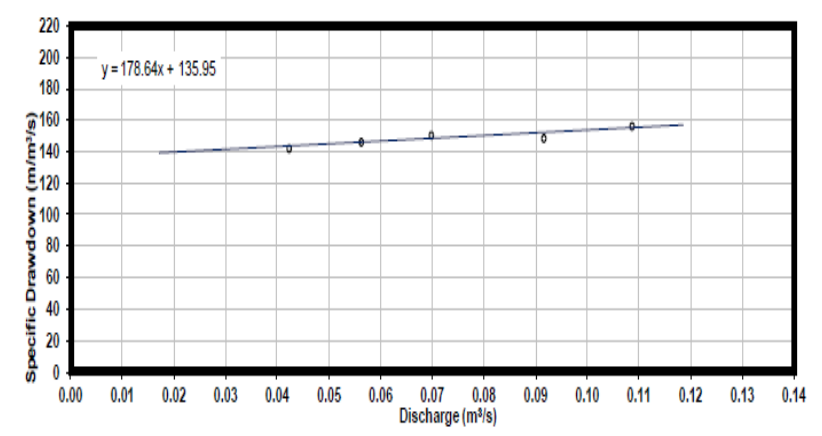

Figure 7. Well specific curve and efficiency

$$
\begin{gathered}
\text { Drawdown }=\mathrm{BQ}+\mathrm{CQ}^{2} \\
\text { Efficiency } \mathrm{E}=\left(\frac{\mathrm{BQ}}{\left(\mathrm{BQ}+\mathrm{CQ}^{2}\right)}\right) * 100 .
\end{gathered}
$$

The Well Specific Capacity can be calculated for each pumping stage (the five steps and the 24-hour steady rate pumping phase). All values are presented in Table 4.

Table 3.Results of the SDPT Analysis and Well Efficiency

\begin{tabular}{|c|c|c|c|c|c|c|}
\hline Step & $\begin{array}{c}\text { Calculated } \\
\text { Drawdown }\end{array}$ & $\begin{array}{c}\text { Cumulative sum of Calculated } \\
\text { Drawdown }\end{array}$ & $\begin{array}{c}\text { Average } \\
\text { Discharge }\end{array}$ & $\begin{array}{c}\text { Average } \\
\text { Discharge }\end{array}$ & $\begin{array}{c}\text { Calculated Specific } \\
\text { Drawdown }\end{array}$ & $\begin{array}{c}\text { Efficiency of the } \\
\text { well }\end{array}$ \\
\hline NO & $\mathrm{m}$ & $\mathrm{m}$ & $\mathrm{m} 3 / \mathrm{s}$ & $\mathrm{M} 3 / \mathrm{day}$ & $\mathrm{m} / \mathrm{m} 3 / \mathrm{day}$ \\
\hline 1 & 6.01 & 6.01 & 0.04219 & 3645.20 & 142.451 \\
\hline 2 & 2.22 & 8.23 & 0.05616 & 4852.00 & 146.552 \\
\hline 3 & 2.29 & 10.52 & 0.06972 & 6024.00 & 150.884 \\
\hline 4 & 3.11 & 13.63 & 0.09149 & 7904.40 & 93.13 & 148.984 \\
\hline 5 & 3.38 & 17.01 & 0.10857 & 9380.80 & & 156.667 \\
\hline
\end{tabular}


Table 4. Summary of the pumping tests data to evaluate well specific capacity

\begin{tabular}{|c|c|c|c|}
\hline $\begin{array}{c}\text { Pumping } \\
\text { phase }\end{array}$ & $\begin{array}{c}\text { Discharge rate* } \\
\text { L/S }\end{array}$ & $\begin{array}{c}\text { Drawdown* } \\
\mathbf{m}\end{array}$ & $\begin{array}{c}\text { Specific capacity } \\
\mathbf{l} / \mathbf{S} / \mathbf{m}\end{array}$ \\
\hline \multirow{4}{*}{ SDPT } & 42.75 & 6.01 & 7.11 \\
\cline { 2 - 4 } & 56.78 & 8.44 & 6.73 \\
\cline { 2 - 4 } & 71.22 & 11.00 & 6.47 \\
\cline { 2 - 4 } & 91.94 & 14.49 & 6.35 \\
\hline \multirow{2}{*}{ SRPT } & 108.83 & 18.29 & 5.95 \\
\hline
\end{tabular}

The aquifer is unconfined. The piezometeric surface in the water level depth between 200m below ground level.

The hydraulic conductivity ranges from 1 to $4 \mathrm{~m} / \mathrm{day}$. The hydraulic characteristics of the Rum aquifer obtained from the drilled wells.

\section{Water Quality}

The results of water quality are also consistent with the water quality of the unconfined aquifer of Rum group. The water quality changes of the two production wells (A3 and A4) during SRPT, presented in Table 5, Table 6 water quality changes of A3 well during the pumping test.

Table 5. Water quality A3 well during pumping test

\begin{tabular}{|l|c|c|c|}
\hline \multirow{2}{*}{ Parameter } & \multirow{2}{*}{ Unite } & \multicolumn{2}{|c|}{ Results } \\
\cline { 3 - 4 } & & Sample 1 & Sample 2 \\
\hline Electrical conductivity & $\mu \mathrm{s} / \mathrm{cm}$ & 383 & 352 \\
\hline Temperature & $\mathrm{C}^{\circ}$ & 22.1 & 22.1 \\
\hline PH & - & 7.79 & 8 \\
\hline Turbidity & $\mathrm{NTU}$ & 2.38 & 0.3 \\
\hline Ca & $\mathrm{Mg} \backslash \mathrm{L}$ & 37.30 & 28.40 \\
\hline $\mathbf{M g}$ & $\mathrm{Mg} \backslash \mathrm{L}$ & 6.12 & 5.22 \\
\hline $\mathbf{N a}$ & $\mathrm{Mg} \backslash \mathrm{L}$ & 30.49 & 16.00 \\
\hline $\mathbf{K}$ & $\mathrm{Mg} \backslash \mathrm{L}$ & 1.71 & 1.20 \\
\hline $\mathbf{C l}$ & $\mathrm{Mg} \backslash \mathrm{L}$ & 28.8 & 20.8 \\
\hline $\mathbf{S O}_{\mathbf{4}}$ & $\mathrm{Mg} \backslash \mathrm{L}$ & 17.52 & 15.63 \\
\hline $\mathbf{H C O}_{3}$ & $\mathrm{Mg} \backslash \mathrm{L}$ & 102 & 94 \\
\hline $\mathbf{N O}_{3}$ & $\mathrm{Mg} \backslash \mathrm{L}$ & 8.5 & 9 \\
\hline Iron & $\mathrm{Mg} \backslash \mathrm{L}$ & $<0.23$ & $<0.15$ \\
\hline
\end{tabular}

Table 6. Water quality A4 well during Pumping Test

\begin{tabular}{|c|c|c|c|c|c|}
\hline \multirow{2}{*}{ Parameter } & \multirow{2}{*}{ Unite } & \multicolumn{2}{|c|}{ Results } & \multicolumn{2}{|c|}{ Results } \\
\hline & & Sample 1 & Sample 2 & Sample 1 & Sample 2 \\
\hline $\begin{array}{l}\text { Electrical } \\
\text { conductivity }\end{array}$ & $\mu \mathrm{s} / \mathrm{cm}$ & 296 & 276 & 323 & 329 \\
\hline Temperature & $\mathrm{C}^{\circ}$ & 21.1 & 21.2 & 29.2 & 29.3 \\
\hline PH & - & 7.97 & 8 & 8.07 & 7.92 \\
\hline Turbidity & NTU & 1.7 & 0.3 & 0.3 & 0.4 \\
\hline Ca & $\mathrm{Mg} \backslash \mathrm{L}$ & 27.3 & 28.40 & 30.4 & 29.4 \\
\hline Mg & $\mathrm{Mg} \backslash \mathrm{L}$ & 4.96 & 5.22 & 5.2 & 5 \\
\hline $\mathrm{Na}$ & $\mathrm{Mg} \backslash \mathrm{L}$ & 16.52 & 16.00 & 18.67 & 17.79 \\
\hline $\mathbf{K}$ & $\mathrm{Mg} \backslash \mathrm{L}$ & 1.20 & 1.20 & 1.3 & 1.2 \\
\hline Cl & $M g \backslash L$ & 20.8 & 20.8 & 24.8 & 23.4 \\
\hline $\mathrm{SO}_{4}$ & $\mathrm{Mg} \backslash \mathrm{L}$ & 15.63 & 15.63 & 20.51 & 18.09 \\
\hline $\mathrm{HCO}_{3}$ & $\mathrm{Mg} \backslash \mathrm{L}$ & 92 & 94 & 113 & 109 \\
\hline $\mathrm{NO}_{3}$ & $\mathrm{Mg} \backslash \mathrm{L}$ & 9.6 & 9.5 & 12.2 & 12.2 \\
\hline Iron & $\mathrm{Mg} \backslash \mathrm{L}$ & $<0.05$ & $<0.05$ & $<0.05$ & $<0.05$ \\
\hline
\end{tabular}

These two Table 5, Table 6, show that water quality changes of the production wells, during pumping test duration. These tables Shows that water quality is excellent and acceptable for drinking purposes, according to the Jordanian water standard 2008 [13], and EU drinking water standard 1998 [14].

At the present time, the Disi- Mudawarra to Amman water conveyance project needs to drill 55 production wells and nine observation wells. The abstracted amounts of water are used for drinking.

The total amounts that were produced from the wells, Range between $100.10^{6}$ million $\mathrm{m}^{3} /$ year. The abstracted amounted from the Disi- Mudawarra area was taken from both the unconfined and confined aquifer area. Throughout the pumping test of were drilled wells during.

The different periods, the hydraulic properties of this aquifer were determined by studies carried out in the well field, beside the pumping test, laboratory measurements and Geophysical log interpretation.

The different hydraulic characteristics of this aquifer either in the confined or in the unconfined area of the aquifer are summaries in Table 7.

Table 7. Hydrogeological summary of recently drilled observation wells in Rum aquifer

\begin{tabular}{|c|c|c|c|c|c|c|c|}
\hline Well No & SWI m & Turbidity NTu & ECps/cm & PH & Discharge Ils & Sand content PPm & Aquifer type \\
\hline B1 & 139.33 & - & $357-395$ & $\begin{array}{l}7.66 \\
7.86\end{array}$ & $5-6 \mathrm{~L} / \mathrm{s}$ & $\begin{array}{l}1.77 \\
1.39 \\
0 \\
0\end{array}$ & Unconfined \\
\hline B2 & 158.37 & $\begin{array}{l}48.32 \\
22.50 \\
13.50 \\
0.00\end{array}$ & $\begin{array}{l}1304-1160 \\
350-459\end{array}$ & 7 & $\begin{array}{l}6 \text { lls } \\
\text { Over a period of 9days }\end{array}$ & $\begin{array}{l}37.00 \\
31.00 \\
14.60 \\
8.71 \\
3.40 \\
1.70 \\
0.3300\end{array}$ & unconfined \\
\hline B3 & 172.37 & $\begin{array}{l}47.50 \\
22.70 \\
11.90 \\
6.10 \\
2.79 \\
\end{array}$ & $1304-383$ & 7.32 & $\begin{array}{l}2.1 \text { and } 4.15 \mathrm{l} / \mathrm{s} \\
\text { Over a time of around } 70 \mathrm{hrs}\end{array}$ & $\begin{array}{l}0.2,0,010 \\
0.00,0.010 \\
0.00\end{array}$ & Unconfined \\
\hline B4 & 127. & $\begin{array}{l}1.09 \\
0.04 \\
0.00\end{array}$ & $625-633$ & 7.92 & 6.45 and $8.7 \mathrm{l} \backslash \mathrm{s}$ & $\begin{array}{l}65.0,25.40 \\
278,0.55 \\
0.27,0.22 \\
0.00,0.44 \\
0.00,0.00\end{array}$ & Unconfined \\
\hline
\end{tabular}


Table 7, this table presents the well location, total depth, to static water level, ground elevation, aquifer depth, discharge $\left(\mathrm{m}^{3} / \mathrm{hr}\right)$ permeability or transmissivity.

The water level decline was very changeable as indicate in the observation wells distributed in the unconfined area of the Rum aquifer system. The water level carried in the observation wells 172.37, 158.37, 139.33m are presented in Table 7.

The piezometric surface in the project area is between 720 and $740 \mathrm{~m}$ amsl, which corresponds to water level depths of between 100 and $200 \mathrm{~m}$ below ground level. The hydraulic conductivity ranges from 1 to $4 \mathrm{~m} /$ day.

Groundwater quality in general is good with Total Dissolved Solids (TDS) around 200 to $300 \mathrm{mg} / \mathrm{l}$. These values correspond electrical conductivity (EC) values around 350 to $400 \mu \mathrm{S} / \mathrm{cm}$, and $\mathrm{pH}$ values around 7 to 7.6. The available water level recorded in the observation wells are not the same.

Figure 8, The development of the well by airlift pumping and backwashing was carried out between Development was undertaken with an average discharge rate of $25.70 \mathrm{l} / \mathrm{s}$ over a period of $2150 \mathrm{~min}$ (35.8 hours). Sand content, turbidity, $\mathrm{pH}$, temperature and EC were measured during airlift discharge Sand content, turbidity, $\mathrm{pH}$, temperature and EC were measured during airlift discharge. The acceptance criteria were met for each section: i.e. Turbidity $<25$ NTU and sand content $<20$ ppm.

The development by over pumping and backwashing was carried out, Over pumping was run with an averaged discharge of 52.98 / $72.31 / 91.95 \mathrm{l} / \mathrm{s}$ over a total period of 1420 min ( 24hours). Static water level at the start the over pumping was at $101.31 \mathrm{mbgl}$.

The acceptance criteria were met for each discharge rate, Turbidity $<5$ NTU and sand content $<2$ ppm.

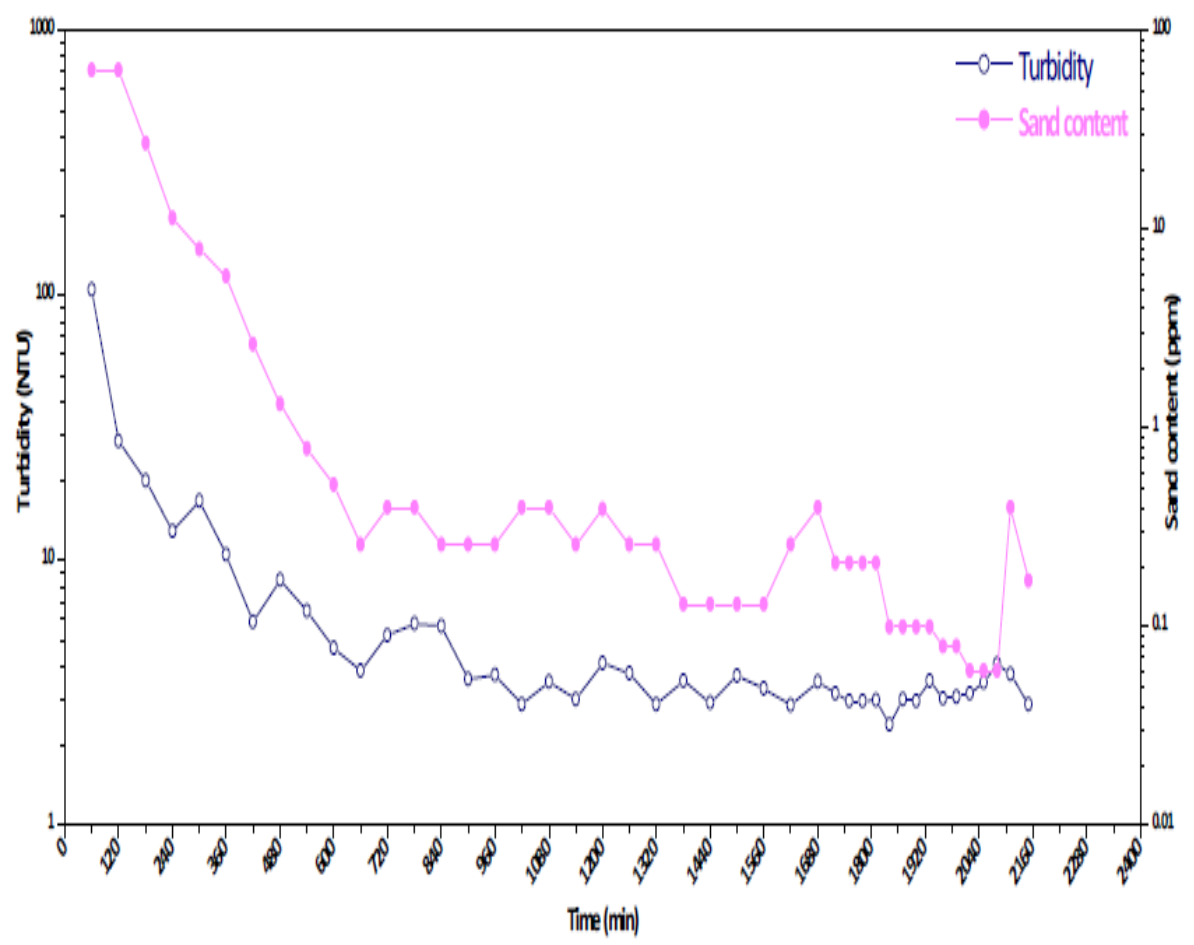

Figure 8. Turbidity and sand content measurements during airlifting and Backwashing

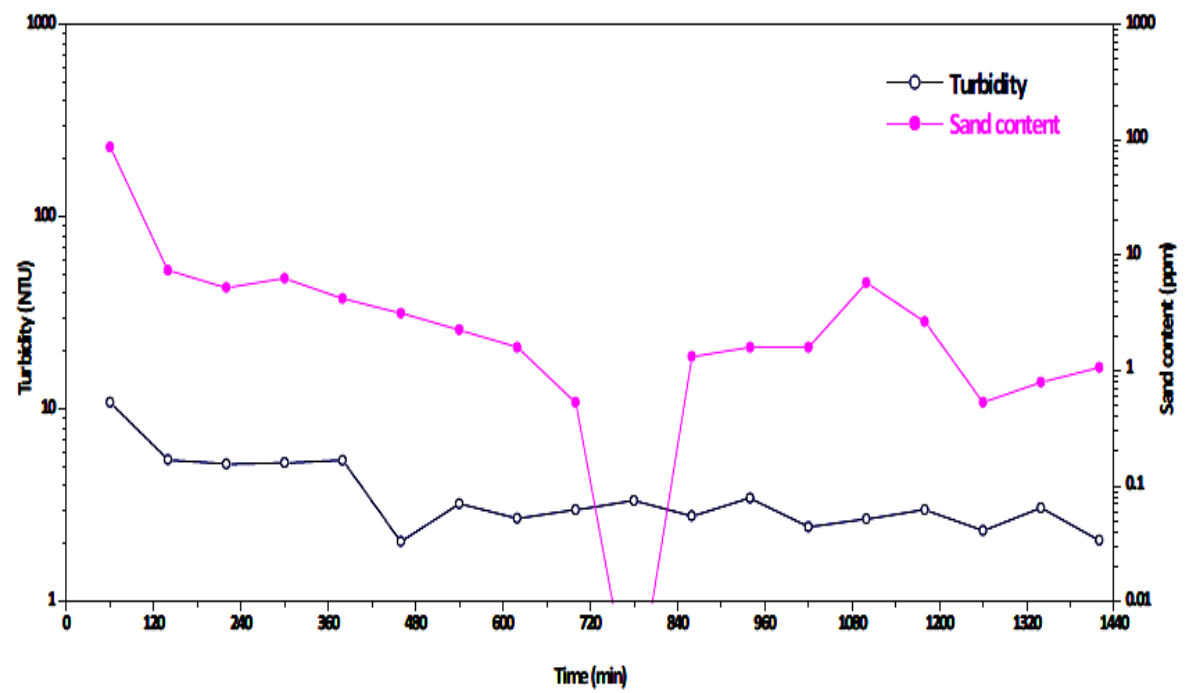

Figure 9. Show the Sand content, turbidity, $\mathrm{pH}$, temperature and EC were measured during airlift discharge 
Table 8. Results of Water Sample Analyses

\begin{tabular}{|c|c|c|c|c|c|c|}
\hline \multirow{3}{*}{ Parameter } & \multirow{3}{*}{ Unit } & \multicolumn{3}{|c|}{ Laboratory Results of sampletaken on } & \multirow{2}{*}{$\begin{array}{c}\text { Jordanian Drinking } \\
\text { Water Standard } \\
2008 \\
\end{array}$} & \multirow{2}{*}{$\begin{array}{c}\text { EU } \\
\text { Drinking Water } \\
\text { Standard } 1998 \\
\end{array}$} \\
\hline & & Sample & Sample & Sample & & \\
\hline & & 1 & 2 & 3 & & \\
\hline Electrical Conductivity & $\mu \mathrm{S} / \mathrm{cm}$ & 625 & 633 & -- & -- & 2500 \\
\hline pH & -- & 8.28 & 7.56 & -- & $6.5-8.5$ & $6.5-9.5$ \\
\hline TDS $\left.^{*}\right)$ & $\mathrm{mg} / \mathrm{l}$ & 450 & 374 & - & 1000 & - \\
\hline True colour & $\mathrm{CU}$ & -- & 25 & 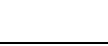 & & \\
\hline Hardness & $\mathrm{mg} / \mathrm{l}$ & 118 & 254 & - & 500 & -- \\
\hline Alkalinity & $\mathrm{mg} / \mathrm{l}$ & 114 & 136.5 & -- & -- & -- \\
\hline Calcium & $\mathrm{mg} / \mathrm{l}$ & 36.47 & 35 & -- & -- & -- \\
\hline Magnesium & $\mathrm{mg} / \mathrm{l}$ & 6.69 & 8.18 & -- & -- & -- \\
\hline Sodium $(\mathrm{Na}+)$ & $\mathrm{mg} / \mathrm{l}$ & 78.89 & 71.42 & -- & 200 & 200 \\
\hline Potassium (K+) & $\mathrm{mg} / \mathrm{l}$ & 1.17 & 1.7 & -- & -- & -- \\
\hline Ammonium (NH4+) & $\mathrm{mg} / \mathrm{l}$ & $<0.1$ & $<0.2$ & -- & 0.2 & 0.5 \\
\hline Chloride (Cl - ) & $\mathrm{mg} / \mathrm{l}$ & 88.4 & 91.5 & -- & 500 & 250 \\
\hline Sulfate $\left(\mathrm{SO}_{4} 2-\right)$ & $\mathrm{mg} / \mathrm{l}$ & 38.88 & 34.51 & -- & 500 & 250 \\
\hline Bicarbonate (HCO3 - ) & $\mathrm{mg} / \mathrm{l}$ & 139.08 & 167 & -- & -- & -- \\
\hline Nitrate $\left(\mathrm{NO}_{3}-\right)$ & $\mathrm{mg} / \mathrm{l}$ & 4.58 & 5.9 & -- & 50 & 50 \\
\hline Carbonate (CO32 - ) & $\mathrm{mg} / \mathrm{l}$ & 0 & 0 & -- & -- & -- \\
\hline Ortho Phosphate & $\mathrm{mg} / \mathrm{l}$ & 0.07 & 0.07 & -- & -- & -- \\
\hline Fluoride (F - ) & $\mathrm{mg} / \mathrm{l}$ & 0.33 & 0.2 & -- & 1.5 & 1.5 \\
\hline Sulfur (S2 - ) & $\mathrm{mg} / \mathrm{l}$ & $<0.2$ & -- & -- & -- & -- \\
\hline Iron (Fe total) & $\mathrm{mg} / \mathrm{l}$ & 0.44 & 5.64 & -- & 1.0 & 0.2 \\
\hline Iron (Fe2+) & $\mathrm{mg} / \mathrm{l}$ & -- & 1.07 & -- & 1.0 & 0.2 \\
\hline Manganese(Mn total) & $\mathrm{mg} / \mathrm{l}$ & 0.95 & 1.18 & -- & 0.1 & 0.05 \\
\hline Manganese(Mn2+) & $\mathrm{mg} / \mathrm{l}$ & -- & 1.06 & -- & 0.1 & 0.05 \\
\hline Aluminum (Al3+) & $\mathrm{mg} / \mathrm{l}$ & -- & 1.06 & - & 0.1 & 0.2 \\
\hline Lead $(\mathbf{P b}+2)$ & $\mathrm{mg} / \mathrm{l}$ & 0.01 & 0.031 & -- & 0.01 & 0.01 \\
\hline Cadmium & $\mathrm{mg} / \mathrm{l}$ & $<0.003$ & $<0.001$ & - & 0.003 & 0.005 \\
\hline Arsenic & $\mathrm{mg} / \mathrm{l}$ & $<0.005$ & -- & -- & 0.01 & 0.01 \\
\hline
\end{tabular}

Table 9. Water quality of DiSi- Mudawarra groundwater resources

\begin{tabular}{|c|c|c|c|c|c|c|c|c|c|c|c|c|c|}
\hline $\begin{array}{l}\text { Well } \\
\text { No }\end{array}$ & Samples & $\begin{array}{c}\text { EC } \\
\mu \mathrm{s} \backslash \mathrm{cm}\end{array}$ & PH & $\begin{array}{c}\mathrm{Ca} \\
\mathrm{mgll}\end{array}$ & $\begin{array}{c}\text { Mg } \\
\text { mgll }\end{array}$ & $\begin{array}{c}\mathrm{Na} \\
\mathrm{mgll}\end{array}$ & $\begin{array}{c}\mathrm{K} \\
\mathbf{m g l l}\end{array}$ & $\begin{array}{c}\mathrm{Cl} \\
\mathrm{mgl}\end{array}$ & $\begin{array}{c}\text { HCO3 } \\
\text { mgll }\end{array}$ & $\begin{array}{l}\mathrm{SO}_{4} \\
\mathrm{mglI}\end{array}$ & $\begin{array}{l}\mathrm{NO}_{3} \\
\mathrm{mgll}\end{array}$ & $\begin{array}{l}\mathrm{CO}_{2} \\
\mathrm{mgl}\end{array}$ & TDS \\
\hline \multirow{2}{*}{ A1 } & 1 & 343 & 7.61 & 35.92 & 6.28 & 17.91 & 1.40 & 23.50 & 108.0 & 18.81 & 12.50 & 113 & 188 \\
\hline & 2 & 366 & 7.83 & 33.96 & 6.14 & 17.20 & 1.30 & 23.0 & 109.0 & 23.75 & 13.80 & 102 & 216 \\
\hline \multirow{2}{*}{ A2 } & 3 & 494 & 7.61 & 37.20 & 6.80 & 65.30 & 6.2 & 68 & 141 & 21.52 & 8.7 & 130 & 296 \\
\hline & 4 & 513 & 7.54 & 37.8 & 7 & 57.3 & 2.1 & 57.8 & - & 21.75 & 9.9 & 105 & 318 \\
\hline \multirow{2}{*}{ A3 } & 5 & 296 & 7.97 & 27.30 & 4.96 & 16.52 & 1.20 & 20.8 & 92 & 15.63 & 9.6 & 175 & 190 \\
\hline & 6 & 276 & 8 & 28.40 & 5.22 & 16.00 & 1.20 & 20.8 & 94 & 15.58 & 9.5 & 111 & 166 \\
\hline \multirow{2}{*}{ A4 } & 7 & 323 & 8.07 & 30.4 & 5.2 & 18.67 & 1.3 & 24.8 & 113 & 20.51 & 12.2 & 128 & 222 \\
\hline & 8 & 329 & 7.92 & 29.4 & 5 & 17.79 & 1.2 & 23.4 & 109 & 18.09 & 12.2 & 125 & 202 \\
\hline \multirow{2}{*}{ A5 } & 9 & 345 & 8.22 & 35.9 & 5.64 & 21.2 & 1.6 & 20.7 & 123 & - & 10.4 & 121 & 209 \\
\hline & 10 & 310 & 8.51 & 37.97 & 5.6 & 20.72 & 1.7 & 20.3 & 116 & - & 10.8 & 111 & 187 \\
\hline \multirow{2}{*}{ A6 } & 11 & 383 & 7.66 & 37.20 & 6.12 & 30.49 & 1.71 & 37.55 & - & 17.52 & 9.89 & 80 & 260 \\
\hline & 12 & 352 & 7.79 & 37.33 & 6.12 & 23.32 & 1.83 & 29.11 & - & 17.28 & 9.48 & 107 & 227 \\
\hline \multirow{2}{*}{ A7 } & 13 & 352 & 7.55 & 32.84 & 6.41 & 31.22 & 1.5 & 40.6 & 49.09 & 27.24 & 7.2 & 104 & 200 \\
\hline & 14 & 363 & 7.54 & 33.44 & 6.44 & 30.37 & 1.5 & 39.9 & 50.77 & 27.14 & 7.2 & 101 & 204 \\
\hline \multirow{2}{*}{ A8 } & 15 & 372 & 8.02 & 37.44 & 6.34 & 28.64 & 1.62 & 40.19 & & 31.18 & 7.83 & 119 & 207 \\
\hline & 16 & 376 & 7.96 & 37.40 & 6.27 & 28.69 & 1.52 & 39.44 & - & 29.10 & 7.88 & 105 & 208 \\
\hline
\end{tabular}

Table 8, shows the results of water samples analysis. The $\mathrm{pH}$ is of major importance in determining the corrosivity of water.
The value of $\mathrm{pH}$ ranges between 7.6 to 8.29 . Table 8 shown electrical conductivity is indicative of the total dissolved solids (TDS 375 to $450 \mathrm{mg} / \mathrm{l}$ in the water. 
These values correspond electrical conductivity (EC) values around 626 to $635 \mu \mathrm{S} / \mathrm{cm}$.

Refer to American Public Health Association (2005) [15], from the inorganic constituents, in both water samples iron and manganese have concentrations above their respective threshold value.

One of the most important characteristics of the water resources of the Rum aquifer is the limited water quality variation either in the aerial or vertical distribution of the aquifer.

The water quality available is presented in Table 9. Selected quality of groundwater production wells during development and redevelopment are shown in Figure 10.

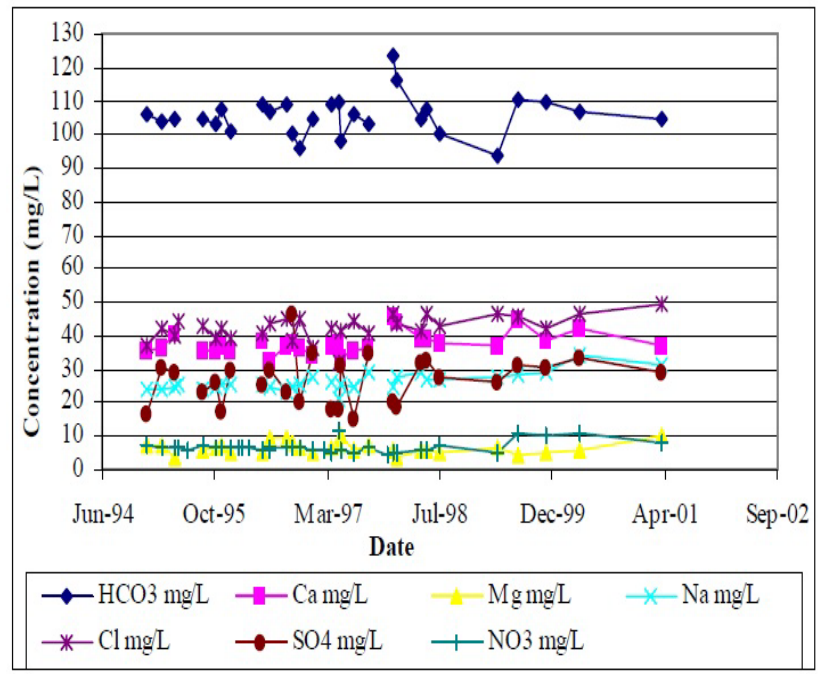

Figure 10. Water quality of DiSi-Mudawarra groundwater resources

Table 9 shows the Natural inorganic constituents commonly dissolved in water that are most likely to affect the use of the water.

Calcium (Ca) with concentration $35.92 \mathrm{mg} / \mathrm{l}$ and magnesium (Mg) with $6.28 \mathrm{mg} / \mathrm{l}$, the major natural sources are Soils and rocks containing limestone, dolomite, and gypsum $\left(\mathrm{Caso}_{4}\right)$ Principal cause of hardness and of boiler scale and deposits in hot water heaters.

Sodium (Na) with concentration $17.91 \mathrm{mg} / \mathrm{l}$ same as for chloride. In some sedimentary rocks, a few hundred milligrams per liter may occur in fresh water as a result of an exchange of dissolved calcium and magnesium for sodium in the aquifer materials.

In large concentrations, may affect persons with cardiac difficulties, hypertension, and certain other medical conditions. Depending on the concentrations of calcium and magnesium also present in the water, sodium may be detrimental to certain irrigated crops. In our case the CL concentration is moderate in the range $30 \mathrm{mg} / \mathrm{l}$.

Bicarbonate $\left(\mathrm{HCO}_{3}\right)$ with concentrations in range 50 to $123 \mathrm{mg} / \mathrm{l}$ and carbonate $\left(\mathrm{CO}_{2}\right)$ Products of the solution of carbonate rocks, mainly limestone $\left(\mathrm{CaCo}_{3}\right)$ and dolomite $\left(\mathrm{CaMgCo}_{3}\right)$, by water containing carbon dioxide, may affect to Control the capacity of water to neutralize strong acids. Bicarbonates of calcium and magnesium decompose in steam boilers and water heaters to form, scale and release corrosive carbon dioxide gas. In combination with calcium and magnesium, causes carbonate hardness.
Sulfate $\mathrm{SO}_{4}$, Gypsum, and other rocks containing sulfur (S) compounds. In certain concentrations, gives water a bitter taste and, at higher concentrations, has a laxative effect. In combination with calcium, forms a hard calcium carbonate scale.

Characteristics of the water that affect water quality. Table 9 shows the characteristics of water quality as following:

- Hardness - Calcium and magnesium dissolved in the water. Calcium and magnesium combine with soap to form an dissolved in the water. Calcium and magnesium combine with soap to form an insoluble precipitate (curd) and thus hamper the formation of a lather. Hardness also affects the suitability of water for use in the textile and paper industries and certain others and in steam boilers and water heaters.

- pH (or hydrogen-ion activity) Dissociation of water molecules and of acids and bases dissolved in water.

The $\mathrm{pH}$ of water is a measure of its reactive characteristics. Low values of $\mathrm{pH}$, particularly below $\mathrm{pH} 4$, indicate a corrosive water that will tend to dissolve metals and other substances that it contacts. High values of $\mathrm{pH}$, particularly above $\mathrm{pH}$ 8.5, indicate an alkaline water that, on heating, will tend to form scale. The $\mathrm{pH}$ significantly affects the treatment and use of water, The $\mathrm{pH}$ value of water Disi- Mudawarra area in a range 7.6 it is mean that the is basic.

- Electrical conductivity $\boldsymbol{\mu s} \backslash \mathbf{c m}$ Substances that form ions when dissolved in Water most substances dissolved in water dissociate into ions that can conduct an electrical current. Consequently, specific electrical conductance is a valuable indicator of the amount of material dissolved in water. The larger the conductance, the more mineralized the water, the electrical conductivity in the range between 330 to 365 micro omhos/cm of water

- Total dissolved solids: Mineral substances dissolved in water. Total dissolved solids are a measure of the total amount of minerals dissolved in water and is, therefore, a very useful parameter in the evaluation of water quality. Water containing total dissolved in the range between 187 to $318 \mathrm{mg} / \mathrm{L}$ is fresh water and excellent quality for drinking.

\section{Conclusion}

Disi- Mudawarra area could still be considered a viable area for a groundwater demonstration project. The area has an abundance of excellent quality groundwater. The groundwater supply from the aquifer Disi Mudawarra to Amman Water Conveyance system Project, were drilled 55 production wells The electrical conductivity ranged between 329and $494 \mu \mathrm{s} \backslash \mathrm{cm}$. These values correspond to 227 and $318 \mathrm{mg} / \mathrm{l}$ of total dissolved solids. Generally, the EC-values of the groundwater resources of the Rum confined and unconfined aquifer range between 276 and $513 \mu \mathrm{s} \backslash \mathrm{cm}$. 


\section{References}

[1] Haiste and Scott Wilsons 1995, "The Rum aquifer system in southern Jordan".

[2] Scott Wilson company, 2002, supervision drilled three wells in Dubaydib area.

[3] Anderws, 1j (1991). Paleozoic lithostratgraphy in the Subsurface of Jordan. Subsurface Geology Bulletin 2, Natural Resources Authority, Amman.

[4] Masri, Ahmad (1988). The Geology of Halat Ammar and AL Mudawarra, Geo Map scale 1:50000-- Map sheets No. 3248- II and 3248 IV the Hashemite kingdom of Jordan - Natural Resources Authority, Geology Directorate, Geological Mapping division --- Bulletin13, Amman.

[5] Masri, Ahmad (2007). The Geology of Dubaydib and Jabal Ladghayn Area, Geo Map -Scale 1:50,000- Map Sheets No.3148Iand 3148-II-The Hashemite kingdom of Jordan -Natural Resources Authority, Geological Directorate, Geological Mapping Division -Bulletin 65, Amman.

[6] Moumani, Khaled Ali. (2003). The Geology of Jabal Umm Sham and Bir as Saladih Area. Geo Map - Scale 1:50,000- Map sheets No. 3148-IV and 3148III- The Hashemite Kingdom of Jordan Natural Resouces Authority, Geology Directorate, Geological Mapping Division - Bulletin 55 - Amman.
[7] De Marsily, G. 1986. Quantitative hydrogeology. Academic Press, London, $440 \mathrm{pp}$.

[8] Bierschenk, W.H. 1963. Determining well efficiency by multiple step-drawdown tests. Intern. Assoc. Sci. Hydrol. Publ. 64, pp. 493 507.

[9] Hantush, M.S. 1966. Analysis of data from pumping tests in anisotropic aquifers. J. layer. J. Geophys. Res., Vol.71, pp. 421426.

[10] Jacob, C.E. 1947. Drawdown test to determine effective radius of artesian well. Trans. Amer. Soc. of Civil. Engrs., Vol. 112, Paper 2321, pp. 1047-1064.

[11] Kruseman G.P., N.A. de Ridder, Analysis and evaluation of Pumping Test Data. Second. Edition. International institute for Land Reclamation and improvement, the Netherlands, 1994. 377P.

[12] Powell, J.H. "stratigraphy and sedimentation of the Paleozoic rocks in central and south Jordan, part A. Geological Mapping Division, Bulletin 11 A Natural Resources Authority, Amman, 1989.

[13] World Health Organization (Guide lines for drinking water Quality, Fourth Edition -564 p,2011).

[14] Jordanian water standard 2008.

[15] American Public Health Association. "Standard Methods for the examination of water and waste water, centennial Edition, 21 Harcdr edition, English, ISBN - 10- 0875550478, ISBN -13-978 08755045. 2005. 